\title{
An atypical case of inverted Tako-Tsubo syndrome: case report and review of the literature
}

\author{
Maurizio Zanobetti $\cdot$ Sonia Vicidomini $\cdot$ \\ Alberto Conti · Francesca Innocenti · \\ Riccardo Pini
}

Received: 21 January 2010/ Accepted: 12 March 2010/Published online: 28 April 2010

(C) SIMI 2010

\section{Case presentation}

Dr. Vicidomini, Dr. Zanobetti, Dr. Innocenti: A 69-yearold Caucasian woman was admitted to our emergency department (ED) for an acute and initial episode of substernal chest pain radiating to the left arm, which had lasted about $1 \mathrm{~h}$, associated with dyspnea and diaphoresis. She had a past medical history of depression and first stage primary biliary cirrhosis. She was taking chronic low-dose sotalol therapy ( $80 \mathrm{mg}$ PO bid) for a prior episode of supraventricular tachycardia. She had an otherwise normal heart, and was without cardiovascular risk factors.

At admission, she denied any recent emotional or stressful event. The first EKG recorded 10 min after the ED admission showed mild ST-segment depression in the precordial leads V5 and V6 (Fig. 1), without significant changes in the inferior, posterior and right precordial leads.

The first blood sample analysis exhibited normal values of Troponin-I (cTn-I: $0.10 \mu \mathrm{g} / \mathrm{L}$, normal range: $0-0.15 \mu \mathrm{g} / \mathrm{L}$ ) and $\mathrm{CK}-\mathrm{MB}(1.1 \mathrm{ng} / \mathrm{ml}$, normal range: $0.5-3.6 \mathrm{ng} / \mathrm{ml})$.

M. Zanobetti - S. Vicidomini - A. Conti · F. Innocenti ·

R. Pini

Department of Critical Care Medicine and Surgery,

University of Florence, Florence, Italy

M. Zanobetti - S. Vicidomini - A. Conti · F. Innocenti ·

R. Pini

Intensive Observation Unit, Careggi University Hospital,

Florence, Italy

\section{Zanobetti $(\square)$}

SOD Osservazione Breve Intensiva,

Azienda Ospedaliero-Universitaria Careggi,

Via delle Oblate, 1, 50141 Florence, Italy

e-mail: zanomau@libero.it
The patient, fully asymptomatic, was admitted to our intensive observation unit.

Based on our protocol, a second blood chemistry control was performed $6 \mathrm{~h}$ after the initial results. An elevated cTn-I value of $3.31 \mu \mathrm{g} / \mathrm{L}$ with normal CK-MB value $(1.0 \mathrm{ng} / \mathrm{ml})$ was observed. The EKG registered at the same time as the laboratory blood tests showed $\mathrm{T}$-wave inversion in the precordial leads from V1 to V4 (Fig. 2), not present in the first tracing,and a small QT dispersion with a QT interval a bit longer than previous EKG. Trans-thoracic echocardiography showed normal left ventricular internal dimensions; the segmental wall motion analysis revealed akinesis of the basal anterior wall and the entire interventricular septum associated with hypokinesis of the inferior wall basal segments. Posterolateral basal segments and all mid-ventricular and apical segments appeared hyperkinetic.

\section{Preliminary diagnosis}

Dr. Zanobetti, Dr. Conti, Dr. Pini: Based on the initial presentation, EKG abnormalities and a positive marker of myocardial necrosis, an acute coronary syndrome, myocarditis, or an atypical presentation of Tako-Tsubo syndrome were considered.

None of the serial EKGs exhibited abnormalities characteristic of an acute coronary syndrome, and there was a mismatch between the limited extension of EKG abnormalities and the diffuse wall motion abnormalities in the echocardiographic examination. This mismatch can support the diagnosis of myocarditid, especially in the presence of limited abnormalities of myocardial specific enzymes. However, all indices of inflammation (C-Reactive Protein, leucocytes, erythrocyte sedimentation rate) 




Fig. 1 First ECG showing mild ST depression in the precordial leads V5-V6



Fig. 2 Second ECG showing T-wave inversion in the precordial leads V1-V4

were in the normal range. The limited EKG abnormalities associated with clear LV wall motion abnormalities can support the diagnosis of Tako-Tsubo syndrome, but the distribution of the wall motion abnormalities was clearly unusual because all the apical segments were unaffected. Thus, the treatment with ACE inhibitors, Ca-blocking agents and Clopidogrel was started, and a coronary angiography was scheduled for the next day. 
$24 \mathrm{~h}$ after the admission, the patient underwent diagnostic coronary angiography that showed absence of significant coronary stenosis. The left ventriculography showed a normal left ventricular cavity without asynergic areas.

\section{Definitive diagnosis}

Dr. Conti, Dr. Innocenti: On the third day, the laboratory tests showed a cTn-I level of $0.64 \mu \mathrm{g} / \mathrm{L}$. The EKG showed a complete resolution of the previous alterations; similarly, the echocardiogram revealed restored normal motion of all the left ventricular segments. cTn-I level at discharge was $0.11 \mu \mathrm{g} / \mathrm{L}$. The patient was discharged fully asymptomatic
4 days after admission, with the indication to continue the pharmacological treatment started in the ED; the final diagnosis was atypical Tako-Tsubo syndrome.

\section{Discussion}

Dr. Zanobetti, Dr. Vicidomini, Dr. Pini: Tako-Tsubo cardiomyopathy, also called stress-induced cardiomyopathy, is a clinical entity first described in Japan [1]. It is characterized by reversible left ventricular apical wall motion abnormalities with typical ischemic type chest pain, electrocardiographic changes, and relatively minor elevation of myocardial enzymes, without angiographic

Table 1 Clinical, electrocardiographic and echocardiographic findings previously described in patients with "inverted Tako-Tsubo".

\begin{tabular}{|c|c|c|c|c|c|c|}
\hline Author & ECG findings & Left ventricular kinetic alterations & $\begin{array}{l}\text { Tn-I }(\mu \mathrm{g} / \\
\mathrm{L})\end{array}$ & $\begin{array}{l}\text { CK-MB } \\
(\mathrm{ng} / \mathrm{ml})\end{array}$ & Age & Sex \\
\hline $\begin{array}{l}\text { Van de Walle } \\
\text { [19] }\end{array}$ & Mild QTc prolongation & Mid and basal akinesis & 0.28 & NA & 41 & $\mathrm{~F}$ \\
\hline Yasu [20] & ST elevation DI, aV1, V2-V5 & Ballooning mid portion & NA & NA & 64 & $\mathrm{~F}$ \\
\hline Kurisu [21] & ST elevation and T-wave inversion in V1-3 & Akinesis of the mid portion & NA & NA & 66 & $\mathrm{~F}$ \\
\hline $\begin{array}{l}\text { Cambronero } \\
{[22]}\end{array}$ & ST elevation in DI, DII, DIII, aVf, V2-V6 & Hypokinesis at the apex & 0.42 & 10.08 & 74 & $\mathrm{~F}$ \\
\hline Fazio [23] & $\begin{array}{l}\text { ST elevation in DI/aVL and T-wave } \\
\text { inversion in all the leads }\end{array}$ & Mid-ventricular akinesis & Normal & Normal & 65 & $\mathrm{~F}$ \\
\hline Yoshida [24] & ST elevation inferior leads & Mid-ventricular akinesis & 0.93 & Normal & 87 & $\mathrm{~F}$ \\
\hline Bulut [25] & ST depression lateral leads & Inferior, septal, basal disfunction & 0.10 & NA & 45 & $\mathrm{~F}$ \\
\hline Rognoni [26] & $\begin{array}{l}\text { ST elevation in the inferior leads and light } \\
\text { ST depression in lateral }\end{array}$ & Infero basal hypokinesis & 3.12 & 11.1 & 50 & $\mathrm{~F}$ \\
\hline Yoshida [27] & $\begin{array}{l}\text { Inverted } \mathrm{T} \text { waves in the inferior and anterior } \\
\text { leads }\end{array}$ & Asynergy at the apex & $\begin{array}{l}\text { Mildly } \\
\text { elevated }\end{array}$ & Normal & 83 & $\mathrm{~F}$ \\
\hline Berti [28] & Mild ST depression in V1-V3 & Mid-infero-postero-lateral akinesis & 0.38 & 14 & 60 & $\mathrm{~F}$ \\
\hline Marti [29] & Diffuse ST changes + RBBB & Basal akinesis & 1.14 & NA & 21 & M \\
\hline $\begin{array}{l}\text { Sanchez- } \\
\text { Recalde } \\
{[30]}\end{array}$ & ST depression V3-V6, DII, DIII, aVF & Basal and midventricular akinesis (pheochro) & Elevated & NA & 41 & $\mathrm{~F}$ \\
\hline $\begin{array}{l}\text { Di Valentino } \\
\text { [31] }\end{array}$ & ST-segment depression V4-V6 & Basal and midventricular akinesis & 4.06 & NA & 52 & $\mathrm{~F}$ \\
\hline Movahed [33] & $\begin{array}{l}\text { Sinus tachycardia and ST depression in } \\
\text { precordial leads }\end{array}$ & Basal akinesis(amphetamine use) & 7 & NA & 25 & $\mathrm{~F}$ \\
\hline \multirow[t]{4}{*}{ Ennezat [10] } & ST depression V4-V6 & Complete akinesis except apex (hematoma) & 26 & Elevated & 34 & M \\
\hline & Peaked $\mathrm{T}$ waves $\mathrm{V} 3-\mathrm{V} 6$ & Complete akinesis except apex (SAH) & 18.5 & Elevated & 29 & M \\
\hline & ST depression DII, DIII, aVF, V4-V6 & Complete akinesis except apex (MS) & 1.14 & Normal & 26 & M \\
\hline & ST elevation V2-V3 & Complete akinesis except apex (epilepsy) & 10 & Elevated & 39 & M \\
\hline $\begin{array}{l}\text { Marechaux } \\
{[32]}\end{array}$ & Inverted $\mathrm{T}$ waves in anterior leads & Complete akinesis except apex (SAH) & 4 & NA & 40 & $\mathrm{~F}$ \\
\hline \multirow[t]{2}{*}{ Tamura [14] } & ST elevation V1-V4 & Ballooning mid portion & NA & NA & 68 & $\mathrm{~F}$ \\
\hline & ST elevation V1-V4 & Ballooning mid portion & NA & NA & 72 & $\mathrm{~F}$ \\
\hline Our data & Mild ST depression V5-V6 & $\begin{array}{l}\text { Akinetic basal anterior and septal walls } \\
\text { Hypokinetic basal inferior wall }\end{array}$ & 3.31 & Normal & 69 & $\mathrm{~F}$ \\
\hline
\end{tabular}

Tn-I Troponine I, NA not available, RBBB right bundle branch block, Pheochro pheochromocytoma, SAH subarachnoid hemorrhage, MS multiple sclerosis 
evidence of epicardial coronary artery stenosis. The condition is confined almost exclusively to elderly women, and is often precipitated by a severe psychological or physical stress, but its pathological basis remains uncertain [2]. The electrocardiographic changes during chest pain are often similar to those found in patients with acute anterior STsegment elevation myocardial infarction (STEMI) [3]. On the other hand, some cases have been described with nonspecific repolarization changes on the admission EKG [4]. In our case, the EKG at the admission showed ST-segment depression and $\mathrm{T}$-wave inversion in the precordial leads associated with an increased cTn-I level at $6 \mathrm{~h}$. Moreover, as occasionally described [5, 6], the second EKG showed an abnormal QT interval not present in the prior tracing.

A careful echocardiographic wall motion analysis is a useful tool for a definite diagnosis. In typical cases, the transthoracic echocardiogram shows akinesia of mid-apical segments with systolic ballooning of the left ventricular apex and contemporary hyperkinetic motion of the basal segments, confirmed by ventriculography. In our case the ventriculography did not show asynergic areas, probably because it was performed after $24 \mathrm{~h}$, when wall motion abnormalities had already disappeared.

Based on anatomic location, four different types of Tako-Tsubo are described in the literature. The "classic type", which is the most commonly reported, is described as apical ballooning or Tako-Tsubo type. The "second type" is the reverse type with hyperdynamic apex and akinesia of left ventricular basal segments (reverse TakoTsubo or reverse apical ballooning type). This type is only rarely described in the literature [7-11]. The "third type" involves the mid left ventricular wall, sparing the base and the apex; it is also called "mid ventricular type" [12-14]. The "fourth type" is characterized by a localized wall motion abnormality affecting a segment of the left ventricular wall, usually the anterior wall [15-18].

In our case, echocardiographic images showed akinesis of the basal anterior wall, and of the entire interventricular septum associated with hypokinesis of the basal segments of the inferior wall (Table 1) [14, 19-33]. Our case combined the anatomic abnormalities previously classified as type two, three and four.

Although the precise mechanism remains unclear, and further studies are necessary to clarify the clinical and pathophysiological features of this syndrome, we would emphasize the importance of promptly thinking of the Tako-Tsubo syndrome. In patients with predisposing clinical factors (e.g., female sex, advanced aged, recent stressful events, typical chest pain, EKG signs of acute ischemia) the combined role of electrocardiogram and transthoracic echocardiography is essential for isolating and identifying possible regional wall motion abnormalities discordant from those predictable at EKG examination, thus suggesting an atypical Tako-Tsubo syndrome with a normal coronary tree.

Conflict of interest None.

\section{References}

1. Dote K, Sato H, Tateishi H, Uchida T, Ishihara M (1991) Myocardial stunning due to simultaneous multivessel coronary spasms: a review of 5 cases. J Cardiol 21:203-214

2. Bybee KA, Kara T, Prasad A, Lerman A, Barsness GW, Wright RS, Rihal CS (2004) Systematic review: transient left ventricular apical ballooning: a syndrome that mimics ST-segment elevation myocardial infarction. Ann Intern Med 141:858-865

3. Tsuchihashi K, Ueshima K, Uchida T, Oh-mura N, Kimura K, Owa M, Yoshiyama M, Miyazaki S, Haze K, Ogawa H, Honda T, Hase M, Kai R, Morii I (2001) Transient left ventricular apical ballooning without coronary artery stenosis: a novel heart syndrome mimicking acute myocardial infarction. Angina pectoris-myocardial infarction investigations in Japan. J Am Coll Cardiol 38:11-18

4. Desmet WJ, Adriaenssens BF, Dens JA (2003) Apical ballooning of the left ventricle: first series in white patients. Heart 89:10271031

5. Matsuoka K, Okubo S, Fujii E, Uchida F, Kasai A, Aoki T, Makino K, Omichi C, Fujimoto N, Ohta S, Sawai T, Nakano T (2003) Evaluation of the arrhythmogenecity of stress-induced "Takotsubo cardiomyopathy" from the time course of the 12-lead surface electrocardiogram. Am J Cardiol 92:230-233

6. Sasaki O, Nishioka T, Akima T, Tabata H, Okamoto Y, Akanuma M, Uehata A, Takase B, Katsushika S, Isojima K, Ohtomi S, Yoshimoto N (2006) Association of takotsubo cardiomyopathy and long QT syndrome. Circ J 70:1220-1222

7. Bonnemeier H, Schafer U, Schunkert H (2006) Apical ballooning without apical ballooning. Eur Heart J 27:2246

8. Bonnemeier H, Ortak J, Burgdorf C, Bode F, Schafer U, Hartmann F, Schunkert H (2007) "The artichoke heart": the inverse counterpart of left ventricular apical ballooning. Resuscitation 72:342-343

9. Haghi D, Papavassiliu T, Fluchter S, Kaden JJ, Porner T, Borggrefe M, Suselbeck T (2006) Variant form of the acute apical ballooning syndrome (Takotsubo cardiomyopathy): observations on a novel entity. Heart 92:392-394

10. Ennezat PV, Pesenti-Rossi D, Aubert JM, Rachenne V, Bauchart JJ, Auffray JL, Logeart D, Cohen-Solal A, Asseman P (2005) Transient left ventricular basal dysfunction without coronary stenosis in acute cerebral disorders: a novel heart syndrome (inverted Takotsubo). Echocardiography 22:599-602

11. Simoes MV, Marin-Neto JA, Maciel BC (2007) Variable regional left ventricular dysfunction in takotsubo cardiomyopathy syndrome. Echocardiography 24:893

12. Ohtsubo M, Sakai H, Takano H, Kon H, Okamoto K, Yoshida N, Fujita M (2005) Atypical takotsubo cardiomyopathy with preservation of apical contraction: a case report including pathological findings. J Cardiol 46:237-242

13. Hurst RT, Askew JW, Reuss CS, Lee RW, Sweeney JP, Fortuin FD, Oh JK, Tajik AJ (2006) Transient midventricular ballooning syndrome: a new variant. J Am Coll Cardiol 48:579-583

14. Tamura A, Kawano Y, Watanabe T, Aso T, Abe Y, Yano S, Kadota J (2007) A report of 2 cases of transient mid-ventricular ballooning. Int J Cardiol 122:e10-e12

15. Suzuki K, Osada N, Akasi YJ, Suzuki N, Sakakibara M, Miyake F, Maki F, Takahashi Y (2004) An atypical case of "Takotsubo cardiomyopathy" during alcohol withdrawal: abnormality in the 
transient left ventricular wall motion and a remarkable elevation in the ST segment. Intern Med 43:300-305

16. Lamm G, Auer J, Eber B (2007) Atypical form of left ventricular ballooning after a violent attack. Int J Cardiol 119:395-397

17. Mazzarotto P, Stecconi P, Gemelli F, Azzarito M, Farnetti F (2005) A case of ballooning syndrome with atypical anterior localization. Ital Heart J Suppl 6:730-734

18. Strunk B, Shaw RE, Bull S, Adams J, Baer M, Gershengorn K, Kao A, Keeffe B, Sklar J, Sperling D, Sperling R, Wexman M, Young J (2006) High incidence of focal left ventricular wall motion abnormalities and normal coronary arteries in patients with myocardial infarctions presenting to a community hospital. J Invasive Cardiol 18:376-381

19. Van de Walle SO, Gevaert SA, Gheeraert PJ, De Pauw M, Gillebert TC (2006) Transient stress-induced cardiomyopathy with an "inverted takotsubo" contractile pattern. Mayo Clin Proc 81:1499-1502

20. Yasu T, Tone K, Kubo N, Saito M (2006) Transient mid-ventricular ballooning cardiomyopathy: a new entity of Takotsubo cardiomyopathy. Int J Cardiol 110:100-101

21. Kurisu S, Inoue I, Kawagoe T, Ishihara M, Shimatani Y, Nakama Y, Ohkawa K, Maruhashi T, Kagawa E, Dai K, Aokage T (2007) Variant form of tako-tsubo cardiomyopathy. Int $\mathrm{J}$ Cardiol 119:e56-e58

22. Cambronero F, Penafiel P, Moreno V, Nolte C, Valdes M (2010) An atypical presentation of Tako-Tsubo cardiomyopathy. Int $\mathbf{J}$ Cardiol 138(3):e53-e55 Epub 2008 Aug 30

23. Fazio G, Novo G, Azzarelli S, Evola S, Barbaro G, Sutera L, Di Gesaro G, Akashi YJ, Novo S (2008) Transient mid-ventricular dyskinesia: a variant of Takotsubo syndrome. Int $\mathrm{J}$ Cardiol 129:272-273

24. Yoshida T, Hibino T, Fujimaki T, Oguri M, Kato K, Yajima K, Ohte N, Yokoi K, Kimura G (2009) Transient mid-ventricular ballooning syndrome complicated by syncope: a variant of takotsubo cardiomyopathy. Int J Cardiol 135:e20-e23
25. Bulut A, Rav-Acha M, Aydin O, Arin CB, Beeri R, Danenberg HD (2009) "Inverted Tako-Tsubo": transient apical-sparing cardiomyopathy. Int J Cardiol 134:e35-e38

26. Rognoni A, Bertolazzi M, Maccio' S, Reale D, Proietti R, Rognoni G (2009) Unusual case of left ventricular ballooning involving the inferior wall: a case report. Cases J 2:140

27. Yoshida T, Nishizawa T, Yajima K, Tsuruoka M, Fujimaki T, Oguri M, Kato K, Hibino T, Ohte N, Yokoi K, Kimura G (2009) A rare case of tako-tsubo cardiomyopathy with variable forms of left ventricular dysfunction: a new entity. Int J Cardiol 134:e73e75

28. Berti M, Gualeni A, Ghizzoni G, Cantamessa P, Oneglia C (2009) Tako-tsubo syndrome: report of a case with mild electrocardiographic changes but with multiple wall motion abnormalities. Int J Cardiol

29. Marti V, Carreras F, Pujadas S, De Rozas JM (2009) Transient left ventricular basal ballooning-"inverted" Tako-tsubo. Clin Cardiol 32:E20-E21

30. Sanchez-Recalde A, Costero O, Oliver JM, Iborra C, Ruiz E, Sobrino JA (2006) Images in cardiovascular medicine. Pheochromocytoma-related cardiomyopathy: inverted Takotsubo contractile pattern. Circulation 113:e738-e739

31. Di Valentino M, Balestra GM, Christ M, Raineri I, Oertli D, Zellweger MJ (2008) Inverted Takotsubo cardiomyopathy due to pheochromocytoma. Eur Heart J 29:830

32. Marechaux S, Fornes P, Petit S, Poisson C, Thevenin D, Le Tourneau T, Asseman P, Bruneval P, Ennezat PV (2008) Pathology of inverted Takotsubo cardiomyopathy. Cardiovasc Pathol 17:241-243

33. Movahed MR, Mostafizi K (2008) Reverse or inverted left ventricular apical ballooning syndrome (reverse Takotsubo cardiomyopathy) in a young woman in the setting of amphetamine use. Echocardiography 25:429-432 